УДК $342.95(477)$

DOI https://doi.org/10.32849/2663-5313/2020.2.42

\title{
Катерина Чишко,
}

канд. юрид. наук,

стариий викладач кафедри полічейської діяльності та публічного адміністрування

Харківського національного університету внутрішніх справ

\section{ДЕРЖАВНА ПОЛІТИКА У СФЕРІ ЗАБЕЗПЕЧЕННЯ ЗМЕНШЕННЯ ВЖИВАННЯ АЛКОГОЛЬНИХ НАПОЇВ І ЇХ ШКІДЛИВОГО ВПЛИВУ НА ЗДОРОВ'Я НАСЕЛЕННЯ: ПРОБЛЕМИ ПРАВОВОГО РЕГУЛЮВАННЯ ТА ШЛЯХИ ЇХ ВИРІШЕННЯ}

\begin{abstract}
Метою статті є з'ясування організаиійно-правового аспекту актуальної державної політики України у сфері забезпечення зменшення вживання алкогольних напоїв, а також визначення прогалин інедоліків чинного законодавства в окресленій сфері, вироблення конкретних пропозииій для усунення останніх. У статті проаналізовано низку нормативно-правових положень і правозастосовчу діяльність у сфері протидії правопорушенням, пов'язаним із роздрібною торгівлею алкогольними напоями, акцентовано увагу на проблемі надмірного споживання алкоголю, зокрема через конкретні недоліки вказаних правових актів. Автором також запропоновано шляхи виправлення останніх, зокрема вжиття більш жорстких заходів юридичної відповідальності. Визначено, що юридична відповідальність є важливим засобом забезпечення охоронної функиії права. Систему иілей юридичної відповідальності становлять: закріплення, впорядкування та вдосконалення суспільних відносин; виховання громадян, підвищення рівня правової культури; формування та забезпечення правомірної поведінки; покарання правопорушника; відновлення порушених суспільних відносин; виправлення та виховання правопорушників; зниження та стабілізація рівня скоєння правопорушень. Зроблено висновок щодо необхідності доповнити Кримінальний кодекс Украӥни положенням про відповідальність за систематичне порушення правил торгівлі алкогольними напоями, визначивши систематичне порушення (три рази та більше протягом року) прачівником підприємства (організачії) торгівлі або громадського харчування правил торгівлі алкогольними напоями, а саме: торгівля алкогольними напоями y приміщеннях або на територіях, заборонених законом, або в інших місиях, визначених рішенням відповідного органу місиевого самоврядування такими, де роздрібна торгівля алкогольними напоями заборонена, а такаж торгівля алкогольними напоями через торгові автомати, продаж алкогольних напої особі, яка не досягла віку вісімнадияти років, або торгівля алкогольними напоями та столовими винами в нічний час, із 22 до 8 години (крім закладів ресторанного господарства).
\end{abstract}

Ключові слова: обіг алкогольної продукції, алкогольні напої, адміністративна відповідальність, публічний порядок, публічна безпека, роздрібна торгівля.

Постановка проблеми. Подолання проблеми надмірного споживання алкоголю, зокрема серед молоді, на жаль, набуває все більшої актуальності. Про це свідчить украй невтішна статистика.

Не залежно від суб'єкта оцінювання, за рівнем споживання алкоголю Україна регулярно потрапляє до першої десятки країн, де споживання алкоголю є найвищим. Так, за офіційними даними Всесвітньої організації охорони здоров'я, кількість споживання алкогольних напоїв на рік в Україні збільшилось 3 трьох літрів (спирту на одну людину) до восьми - дев'яти літрів, починаючи із 2006 р. [1]. Лише за результатами 2017 р.
Україна посіла друге місце в рейтингу найбільш питущих країн Свропи [2].

За результати соціологічного опитування «Куріння, вживання алкоголю та наркотичних речовин серед підлітків, які навчаються: поширення й тенденції в Україні», проведеного ГО «Український інститут соціальних досліджень імені Олександра Яременка» у 2015 р. в рамках міжнародного проєкту «Європейське опитування учнів щодо вживання алкоголю та інших наркотичних речовин», 83,4\% учнів уживали будьякі напої хоча б один раз упродовж життя. $11 \%$ учнів зазначили, що почали вживати міцні алкогольні напої у віці 15 років. Крім 
того, 34,5\% учнів вказали на те, що їм «легко» або «дуже легко» придбати алкогольні напої. Найбільш доступними виявилися слабоалкогольні напої (ї вказали 51,5\% опитаних) та пиво $(59,5 \%)[3]$.

Думки вітчизняних та іноземних учених стосовно неприпустимості вживання слабоалкогольних напоїв, зокрема пива, дітьми та підлітками єдина. Доведено, що найбільш небезпечно для виникнення залежності вживання алкоголю молодими людьми до 18-20-річного віку, тому що в період інтенсивного зростання клітини мозку й інші органи найбільш чутливі до шкідливих впливів. Пивний алкоголізм особливо поширений серед молодих людей. Захворювання в цих пацієнтів зазвичай прогресує дуже швидко, супроводжується важкими психічними розладами, деградацією особистості, важко піддається лікуванню. Ученими встановлено, що чим у більш ранньому віці розпочато систематичне вживання алкоголю, тим частіше трапляються випадки тяжких соціальних і медичних наслідків, швидше розвивається алкоголізм, незалежно від освіти, етнічної належності, сімейного становища, спадковості (висновок кафедри наркології Харківської медичної академії післядипломної освіти, 24 червня 2004 р.) [4]

Вражають негативні наслідки вживання алкоголю. Зокрема, за даними Міністерства охорони здоров'я, в Україні наявна дуже гостра проблема розладів, що спричинені надмірним уживанням алкоголю. Спеціалісти підрахували, що 40\% смертей чоловіків працездатного віку та 22\% жінок віком від 20 до 64 років є наслідком уживання алкоголю [5].

Зважаючи на соціальну значущість обраної тематики, варто зазначити, що різні аспекти регулювання національної сфери алкогольних виробів стали темою праць низки вчених, зокрема в галузі адміністративного права, наприклад: В.А. Бабич, Ю.С. Мостович [6] з'ясовували специфіку провадження у справах щодо продажу алкогольних напоїв і тютюнових виробів неповнолітнім особам; В.А. Бернадін [7] запропонував поняття та класифікацію адміністративних правопорушень у сфері обігу підакцизних товарів; Т.М. Біденчук і В.П. Кононець [8] систематизували підстави адміністративної відповідальності у сфері обігу алкогольних напоїв, а монографічне дослідження С.О. Рядінського [9] присвячене фінансово-правовому регулюванню виробництва й обігу алкогольної продукції.

Водночас проблеми законодавчої регламентації державної політики у сфері забезпечення зменшення вживання алкогольних напоїв та їхнього шкідливого впливу на здоров'я населення дотепер сьогодні не були комплексно висвітлені, як і не вироблено систематичні шляхи їх вирішення.

Мета статті полягає в з'ясуванні організаційно-правового аспекту актуальної державної політики України у сфері забезпечення зменшення вживання алкогольних напоїв, а також визначення прогалин і недоліків чинного законодавства в окресленій сфері, вироблення конкретних пропозицій для усунення останніх.

Виклад основного матеріалу. Чинне законодавство України визначає основні засади державної політики щодо всіх сфер виробництва й обігу спирту етилового, коньячного і плодового, спирту етилового, ректифікованого виноградним, спирту етилового, ректифікованого плодовим, дистиляту виноградного спиртового, спирту-сирця плодового й алкогольних напоїв, зокрема їх оптової та роздрібної торгівлі. Відповідні законодавчі положення піддаються систематичному вдосконаленню. Водночас описаний нами стан справ є яскравим прикладом недосконалості правової системи регулювання обігу та торгівлі алкогольними напоями і сировиною для їх виготовлення.

У свою чергу, аналіз деяких нормативноправових положень і правозастосовчої діяльності у сфері протидії правопорушенням, пов'язаним із роздрібною торгівлею алкогольними напоями, дають підстави виокремити їхні конкретні недоліки, запропонувати шляхи вирішення проблеми. Серед них такі.

1. Лише 22 березня 2018 р. увхалено Закон України «Про внесення змін до деяких законодавчих актів України щодо надання органам місцевого самоврядування повноважень встановлювати обмеження продажу пива (крім безалкогольного), алкогольних, слабоалкогольних напоїв, вин столових» [10], яким передбачено надання органам місцевого самоврядування спеціальних повноважень установлювати в межах відповідної адміністративної території обмеження (заборони) продажу пива (крім безалкогольного), алкогольних, слабоалкогольних напоїв, столових вин у визначений час доби, передбачено відповідальність за їх недотримання. Ухвалення цього Закону зумовлено практикою запровадження відповідних рішень органами місцевого самоврядування, на території поширення повноважень яких зафіксовані факти систематичного порушення тиші та громадського правопорядку в нічний час біля об'єктів торгівлі алкогольними напоями та, як наслідок, успішного оскарження таких 
рішень суб’єктами підприємницької діяльності в судах.

Схвально оцінюючи значний профілактичний як загальносоціальний, так і правоохоронний ефект запровадження згаданого Закону ${ }^{1}$, уважаємо, що вжиття передбачених ним заходів недостатньо. Так, продавати алкоголь уночі заборонять ті міста, що мають профіцит бюджету і можуть дозволити собі дбати про комфорт громадян. Натомість ті місцеві ради, які відчувають дефіцит коштів, звісно, такої заборони вводити не будуть, адже від усього проданого алкоголю $5 \%$ акцизного податку надходить до місцевого бюджету (п. 16 ч. 1 ст. 64 Бюджетного кодексу України [11] та ст. 215 Податкового кодексу України [12]). Крім того, така заборона жодним чином не вплине на функціонування дрібних закладів торгівлі чи громадського харчування, які часто вже функціонують із порушенням закону, адже їніми клієнтами переважно є особи, які намагаються придбати алкоголь за відсутності контролю (наприклад, неповнолітні) або вже перебувають у стані алкогольного сп'яніння, тоді як громадяни, які бажають придбати алкоголь для святкування якихось подій, здійснять це завчасно.

Відповідно до ст. ст. 3 та 16 Конституції України, життя, здоров'я та безпека українців $€$ найвищою соціальною цінністю, а збереження генофонду українського народу є обов'язком української держави. Тому вважаємо, що питання заборони продажу алкоголю в нічний час є питанням відповідальності загальнодержавного характеру. Зокрема, уряди різних країн давно усвідомили негативні наслідки для здоров'я населення від вживання алкоголю саме в нічний час. Так, позитивними нормами, що зменшують споживання алкоголю в Данії, Норвегії та Швеції, є легальна торгівля алкоголем лише державними торговельними мережами і лише з 10 до 18 годин, а в неділю торгівлю заборонено. У Латвії та Литві заборонено торгівлю алкоголем та пивом із 22 до 8 години. В Англії торгівлю алкоголем та пивом дозволено лише до 23 годин (навіть у пабах), пізніше дозволяється торгувати алкоголем лише в тих закладах, які мають офіційних статус «нічного клубу» й отримали спеціальну ліцензію (Licensing Act of 2003). За офіційною інформацією Департаменту (Міністерства) культури, інформації та спорту Великої Британії (Department

1 Загальновідомо, що більшість правопорушень у сфері громадського порядку та безпеки вчиняються саме в нічний час доби особами, які переважно перебувають у нетверезому стані. for Culture, Media and Sport), тільки 0,02\% із закладів (без урахування готелів), які торгують алкоголем на території Великої Британії, мають право торгувати алкогольними виробами не до 23 години, а цілодобово [4].

2. Відповідальність за порушення правил торгівлі пивом, алкогольними, слабоалкогольними напоями встановлена ст. 156 Кодексу України про адміністративні правопорушення [13] (далі - КУпАП). Розгляд справ про адміністративні правопорушення, передбачені у ст. 156 КУпАП, віднесено до компетенції суду (ч. ч. 1, 3, 4) (ст. 221 КУПАП) і адміністративних комісій при виконавчих органах міських, сільських, селищних рад (ст. 218 КУПАП) або центрального органу виконавчої влади, що реалізує державну політику у сфері державного контролю за додержанням законодавства про захист прав споживачів (ст. 244-4 КУ ПАП).

У ст. 255 КУ ПАП право на складення протоколу про адміністративне правопорушення, передбаченого ст. 156 КУпАП, надано уповноваженим на те посадовим особам органів Національної поліції, центрального органу виконавчої влади, що реалізує державну політику у сфері державного контролю за додержанням законодавства про захист прав споживачів, і посадовим особам, уповноваженим на те виконавчими комітетами сільських, селищних, міських рад (за порушення, учинені в місцях, заборонених рішенням відповідної сільської, селищної, міської ради).

На особливу увагу заслуговує практика забезпечення притягнення до відповідальності осіб, які вчинили адміністративні правопорушення, передбачені ч. 2 ст. 156 КУ ПАП, якими, зокрема, є «порушення працівником підприємства (організації) торгівлі або громадського харчування правил торгівлі пивом (крім безалкогольного), алкогольними, слабоалкогольними напоями і тютюновими виробами, а саме: торгівля пивом (крім безалкогольного), алкогольними, слабоалкогольними напоями або тютюновими виробами у приміщеннях або на територіях, заборонених законом, або в інших місцях, визначених рішенням відповідного органу місцевого самоврядування як такі, де роздрібна торгівля пивом (крім безалкогольного), алкогольними, слабоалкогольними напоями або тютюновими виробами заборонена, а так само торгівля пивом (крім безалкогольного), алкогольними, слабоалкогольними напоями або тютюновими виробами через торгові автомати чи неповнолітніми особами, а також продаж пива (крім безалкогольного), алкогольних, слабоалкогольних напоїв або тютюнових 
виробів особі, яка не досягла 18 років, або продаж тютюнових виробів в упаковках, що містять менш як 20 сигарет або цигарок, чи поштучно (крім сигар), або торгівля пивом (крім безалкогольного), алкогольними, слабоалкогольними напоями, винами столовими в заборонений рішенням відповідного органу місцевого самоврядування час доби».

Чинні нормативно-правові положення процесу розгляду справ про адміністративні правопорушення, передбачені в ч. 2 ст. 156 КУпАП, не забезпечують належного притягнення осіб, які вчинили відповідні правопорушення, до відповідальності. Такий стан речей зумовлений саме суб'єктом розгляду справи про адміністративне правопорушення за ч. 2 ст. 156, про що йшлося вище. Наслідком цього є найкоротший строк накладення адміністративного стягнення, a саме: «два місяці із дня вчинення правопорушення, а при триваючому правопорушенні - не пізніш як через два місяці із дня його виявлення» (ст. 38 КУпАП). У свою чергу, ст. 268 КУПАП установлено: «Справа про адміністративне правопорушення розглядається лише у присутності особи, яка притягається до адміністративної відповідальності. Під час відсутності цієї особи справу може бути розглянуто лише у випадках, коли є дані про своєчасне їі сповіщення про місце і час розгляду справи і якщо від неї не надійшло клопотання про відкладення розгляду справи».

Практика забезпечення притягнення осіб, які вчинили адміністративні правопорушення за ч. 2 ст. 156 КУпАП, до відповідальності свідчить, що відповідні особи досить легко уникають відповідальності через можливість максимального затягування часу розгляду справи (більше 2 місяців), що $є$ однією з обставин, яка виключає провадження у справі про адміністративне правопорушення (п. 7 ч. 1 ст. 247 КУпАП). Крім того, немає також правових механізмів забезпечення залучення особи до розгляду справи про адміністративне правопорушення. Так, привід особи поліцейськими здійснюється виключно до суду лише в разі розгляду ним обмеженого кола справ про адміністративне правопорушення.

Вирішення описаної правозастосовної проблеми може бути забезпечено шляхом зміни суб'єкта розгляду справи про адміністративне правопорушення за ч. 2 ст. 156 КУпАП. Такими органами можуть стати суд (у такому разі всі правопорушення, передбачені у ст. 156 КУпАП, будуть підвідомчі суду) або органи Національної поліції (поліцейські є основним суб'єктом, які нині складають протоколи про адміністративні правопорушення за ч. 2 ст. 156, тому надання їм відповідних повноважень забезпечить найоперативнішу можливість реагування на такі правопорушення шляхом розгляду справи про адміністративне правопорушення на місці його вчинення).

3. Юридична відповідальність виступає важливим засобом забезпечення охоронної функції права. Перша $є$ якісним показником реального втілення прав і свобод особи в соціальній дійсності. Водночас виявляються ціннісні орієнтири держави, рівні цивілізованості суспільства, духовності та культурності населення, а також наявність законодавчих гарантій і механізмів захисту прав і свобод особи.

Систему цілей юридичної відповідальності становлять: закріплення, упорядкування та вдосконалення суспільних відносин; виховання громадян, підвищення рівня правової культури; формування та забезпечення правомірної поведінки; покарання правопорушника; відновлення порушених суспільних відносин; виправлення та виховання правопорушників; зниження та стабілізація рівня скоєння правопорушень.

Як уявляється, описаний нами стан справ 3 украй негативними наслідками вживання алкоголю, що значним чином пов'язано 3 незаконним обігом та торгівлею алкогольними напоями, ураховуючи цілі юридичної відповідальності, потребує встановлення більш жорстких заходів юридичної відповідальності. Зокрема, уважаємо за доцільне передбачити кримінальну відповідальність за систематичні порушення правил торгівлі алкогольними напоями.

\section{Висновки}

Отже, нами описані основні актуальні проблеми правового регулювання зменшення вживання алкогольних напоїв та їхнього шкідливого впливу на здоров'я населення. Також запропоновані основні напрями вирішення проблем, які можуть бути втілені в таких законодавчих змінах:

1. Заборонити торгівлю алкоголем у нічний час (22.00-8.00), для чого пропонуємо:

- ч. 1 ст. 15-3 Закону України «Про державне регулювання виробництва і обігу спирту етилового, коньячного і плодового, алкогольних напоїв та тютюнових виробів» доповнити окремим пунктом такого змісту:

«12) у нічний час, із 22 до 8 години (крім закладів ресторанного господарства)»;

- ч. 9 ст. 15-3 Закону України «Про державне регулювання виробництва і обігу спирту етилового, коньячного і плодового, алкогольних напоїв та тютюнових виробів» видалити; 
- в абз. 1 ч. 2 ст. 156 Кодексу України про адміністративні правопорушення слова «заборонений рішенням відповідного органу місцевого самоврядування час доби» замінити на слова «у нічний час, із 22 до 8 години (крім закладів ресторанного господарства)»;

- п. 44-1 ч. 1 ст. 26 Закону України «Про місцеве самоврядування в Україні» виключити.

2. Внести такі зміни до Кодексу України про адміністративні правопорушення:

- у ст. 221 перед цифрами «156» слова «частинами першою, третьою і четвертою статті» виключити, перед цифрами «155-1» слово «статтею» замінити на слово «статтями» (у разі віднесення повноваження щодо розгляду справи про адміністративне правопорушення за ч. 2 ст. 156 до компетенції суду)

або

- у ст. 222 після цифр «151» перед словами та цифрами ст. 161 доповнити словами та цифрами «частиною другою статті 156» (у разі віднесення повноваження щодо розгляду справи про адміністративне правопорушення за ч. 2 ст. 156 до компетенції Національної поліції);

- у ст. 218 слова та цифри «частиною другою статті 156» виключити.

3. Кримінальний кодекс України доповнити статтею такого змісту:

«С. 204-1 «Систематичне порушення правил торгівлі алкогольними напоями»

1. Систематичне порушення (три та більше рази протягом року) працівником підприємства (організації) торгівлі або громадського харчування правил торгівлі алкогольними напоями, а саме: торгівля алкогольними напоями у приміщеннях або на територіях, заборонених законом, або в інших місцях, визначених рішенням відповідного органу місцевого самоврядування як такі, де роздрібна торгівля алкогольними напоями заборонена, а так само торгівля алкогольними напоями через торгові автомати, а також продаж алкогольних напоїв особі, яка не досягла 18 років, або торгівля алкогольними напоями та винами столовими в нічний час, із 22 до 8 години (крім закладів ресторанного господарства), -

карається штрафом від п'ятисот до семисот п'ятдесяти неоподатковуваних мінімумів доходів громадян із конфіскацією предметів торгівлі.

2. Дії, передбачені ч. 1 цієї статті, пов'язані з торгівлею незаконно виготовлених алкогольних напоїв, -

караються штрафом від семисот п’ятдесяти до однієї тисячі неоподатковуваних мінімумів доходів громадян із конфіскацією предметів торгівлі».

\section{Список використаних джерел:}

1. Ежегодное потребление алкоголя, литры чистого спирта на человека, население возрастом $15+$ лет. Европейский портал информации здравоохранения. Официальный веб-портал Европейского регионального бюро Всемирной организаиии здравоохранения. URL: https://gateway.euro.who. int/ru/indicators/hfa 426-3050-pure-alcoholconsumption-litres-per-capita-age-15plus/visuali zations/\#id=19443\&tab=table (дата звернення: 17.08.2019).

2. Україна вийшла на друге місце в рейтингу найбільш п'ющих країн. Суспільство. Офічійний вебсайт «Business UA».URL:http://businessua.com/ suspilstvo/43068ukraina-viishla-na-druge-misce-vreitingu-naibilsh-pyuszih-krain.html\# (дата звернення: 03.09.2019).

3. В Україні понад $83 \%$ підлітків вживали алкоголь - опитування. Офімійний вебсайт інформачійного агентства УНIAH. URL: https://health.unian.ua/country/1530761-vukrajini-834-pidlitkiv-mayut-dosvid-vjivannyaalkogolyu-sotsopituvannya.html (дата звернення: 14.09.2019).

4. Пояснювальна записка до проєкту закону України «Про внесення змін до деяких законодавчих актів України (заборони торгівлі алкоголем в нічний час)» від 24 лютого 2017 р. Офіиійний вебпортал Верховної Ради Украіни. URL: http://w1.c1.rada.gov.ua/pls/zweb2/ webproc4_1?pf3511=61227 (дата звернення 15.09.201 $\overline{9})$.

5. Стало відомо, скільки українців вмирає від алкоголізму. Офіиійний вебсайт «Еспресо». URL: https://espreso.tv/news/2017/11/03/stalo vidomo_skilky_ukrayinciv_vmyraye_vid_ alkogolizmu (дата звернення: 28.099.2019).

6. Бабич В.А., Мостович Ю.С. Провадження у справах щодо продажу алкогольних напоїв тютюнових виробів неповнолітнім особам. Молодий вчений. 2017. № 3. С. 530-533.

7. Бернадін В.А. Поняття та класифікація адміністративних правопорушень у сфері обігу підакцизних товарів. Підприємниитво, господарство і право. 2019. № 12. С. 160-164.

8. Біденчук Т.М., Кононець В.П. Підстави адміністративної відповідальності у сфері обігу алкогольних напоїв та тютюнових виробів. Юридичний науковий електронний журнал. 2018. № 6. C. 193-196. URL: http://www.lsej.org ua/6_2018/52.pdf (дата звернення: 10.08.2019).

9. Рядінський Є.О. Фінансово-правове регулювання виробництва та обігу алкогольної продукції в Україні : автореф. дис. ... канд. юрид. наук: 12.00.07. Київ, 2018. 21 с.

10. Про внесення змін до деяких законодавчих актів України щодо надання органам місцевого самоврядування повноважень встановлювати обмеження продажу пива (крім безалкогольного), алкогольних, слабоалкогольних напоїв, вин столових : Закон України від 22 березня 2018 р. № 2376-VIII. Офіиійний вісник Украӥни. 2018 № 36. Ст. 11. 
11. Бюджетний кодекс України : Закон України від 8 липня 2010 р. № 2456-VI. Відомості Верховної Ради України. 2010. № № 50-51. Ст. 572.

12. Податковий кодекс України : Закон України від 2 грудня 2010 р. № 2755-VI. Відо- мості Верховної Ради Украӥни. 2011. № № 13-17. Ст. 112.

13. Кодекс України про адміністративні правопорушення від 7 грудня 1984 р. № 8073-Х. Вiдомості Верховної Ради Української Радянської Соиіалістичної Республіки. 1984. Дод. до № 51. Ст. 1122.

The purpose of the article is to find out the organizational and legal aspect of the current state policy of Ukraine in the sphere of ensuring the reduction of alcoholic beverages, as well as to identify the gaps and shortcomings of the current legislation in the specified field, to develop specific proposals for the elimination of the latter. The article analyzes a number of legal provisions and law enforcement activities in the field of combating offenses related to the retail sale of alcoholic beverages, as a result of which attention is focused on the existence of the problem of excessive alcohol consumption, including due to specific shortcomings in these legal acts. The author also proposed solutions to the latter, including the establishment of more stringent measures of legal liability. Legal responsibility has been identified as an important means of ensuring the security function of law. The system of goals of legal responsibility are: consolidation, ordering and improvement of social relations; education of citizens, raising the level of legal culture; formation and maintenance of laweful behavior; punishment of the offender; restoration of broken social relations; correcting and educating offenders; reduction and stabilization of the crime rate. It is concluded that it is necessary to supplement the Criminal Code of Ukraine with responsibility for the systematic violation of the rules of trade in alcoholic beverages, defining the systematic violation (three or more times during the year) by an employee of the enterprise (organization) of trade or public catering of the rules of trade in alcoholic beverages, namely: alcoholic beverages trading in alcoholic beverages or in territories prohibited by law or in other places designated by decision of the relevant local government, such as where retail and the sale of alcoholic beverages is prohibited, as well as the sale of alcoholic beverages through vending machines, as well as the sale of alcoholic beverages to persons under 18 years of age, or the sale of alcoholic beverages and table wines at night from 22 to 8 o'clock (except restaurants).

Key words: turnover of alcoholic beverages, alcoholic beverages, administrative responsibility, public policy, public safety, retail. 